\title{
Factors Affecting Antibacterial and Antifungal Properties of Microemulsion Gel containing Tea Tree Oil
}

\author{
Raditya Weka Nugraheni ${ }^{1, *}$ Uswatun Chasanah² Mohammad Dzulkifli Maulana ${ }^{3}$ \\ Miftakhur Ridha Ayyunaini ${ }^{4}$ Umma Istiqomah Dwiputri ${ }^{5}$ Rizki Ayu Firnanda ${ }^{6}$
}

\author{
1,2,3,4,5,6 Department of Pharmacy, Faculty of Health Science, University of Muhammadiyah Malang, Indonesia \\ *Corresponding author. Email: radityawn@umm.ac.id
}

\begin{abstract}
Tea tree oil (Melaleuca alternifolia) has been acknowledged for its antibacterial and antifungal properties. Previous publications revealed that the tea tree oil has antibacterial activity against Propionibacterium acnes, which is the leading cause of acne, Staphylococcus aureus that caused various skin infections, and antifungal activity against Candida albicans. In this work, we aim to investigate the effect of microemulsion preparations in various gelling agents to their antibacterial and antifungal properties. Microemulsions have smaller droplets size than conventional emulsions; thus, we hypothesized that there would be a different effect on their inhibitory properties. The tea tree oil is formulated into a microemulsion and conventional emulsion, followed by incorporation into different gelling agents: Carbopol 940, Hydroxy-propyl methylcellulose, and sodium alginate. Physicochemical properties, such as pH, viscosity, and physical stability, had also been tested. The antibacterial and antifungal properties were tested using agar well diffusion methods. The microemulsion size was $(26.23+0.15) \mathrm{nm}$, the $\mathrm{pH}$ of the final gel formulations was 4 to 7 , and all formulations were physically stable under room temperature. The diameter of inhibition zones against bacteria and fungus was statistically analyzed using the multifactorial ANOVA method. The factors significantly affecting antibacterial and antifungal activities are the species of fungus and bacteria (p <0.001), gelling agents in formulations $(\mathrm{p}<0.05$ ), and emulsions preparations $(\mathrm{p}<0.001)$. It was also interesting to note that these factors were significant on the activities tested $(\mathrm{p}<0.05)$.
\end{abstract}

Keywords: Microemulsion, Tea tree oil, antibacterial, antifungal

\section{INTRODUCTION}

Tea Tree Oil (TTO) is an essential oil primarily derived from the Melaleuca alternifolia plant native to Australia. Mostly used as an antimicrobial and used as an active ingredient in topical preparation formulations used to treat skin infections in Australia, Europe, and North America.[1]. Terpinene-4-ol is the main component of tea tree oil, which has strong antimicrobial activity[2]. This research aims to optimize the activity of these active ingredients; it is necessary to carry out investigations to find out what factors influence it. This study aims to determine the effect of differences in gelling agents in gel microemulsion preparations containing TTO on several microbial species that cause skin infections, namely Propionibacterium acnes, Staphylococcus aureus, and the fungus Candida albicans.

\section{MATERIAL AND METHODS}

\subsection{Materials}

The instruments used are Analytical Balance (Shimadzu), pH meter (SI Analytics Lab 845), Electric Homogenizer
(Heidolph), Viscometer (Brookfield), Particle Size Analyzer (Horiba Scientific, Nano Particle Analyzer SZ-100).

The materials used are Tea Tree Oil (Happy Green), Polysorbate 80 (Bratachem), propylene glycol (Dow Chemical Pacific), Carbopol 940 (Dow Chemical Pacific), Triethanolamine (TEA, Bratachem), Hydroxy-propyl methylcellulose (Dow Chemical Company), Na-Alginate (Yantai Sheli Hydrocolloids), $\mathrm{CaCl} 2$ (Bratachem), NaEDTA (AkzoNobel), Methylparaben (Ueno Fine Chemicals), Propylparaben (Ueno Fine Chemicals), Purified water (Bratachem).

\subsection{Methods}

In this research, a tea tree oil microemulsion gel was prepared. This research was carried out by making three formulas for the Tea Tree Oil microemulsion gel preparation, which will then be carried out by organoleptic test, $\mathrm{pH}$ test, viscosity test, spread-ability test, homogeneity test, and stability test (real-time and freeze-thaw), continued by antibacterial and antifungal activity tests.

The tea tree oil microemulsion prepared according to our previous publications [3]using 20\% of Polysorbate 80 and $10 \%$ of Propylene Glycol as surfactant and co-surfactants. The microemulsions were then formulated into gel 
preparations: 1\%Carbopol 940, 5\% HPMC, and 5\% sodium alginate (Table 1).

Table 1. Formulations of TTO Microemulsion Gel Preparations

\begin{tabular}{|l|l|l|l|l|}
\hline Materials & Functions & F1 & F2 & F3 \\
\hline $\begin{array}{l}\text { 3.3\% TTO } \\
\text { microemulsions }\end{array}$ & $\begin{array}{l}\text { Active } \\
\text { Ingredients }\end{array}$ & 75 & 75 & 75 \\
\hline Carbopol ® 940 & Gelling agent & 1 & - & - \\
\hline TEA & Alkalizing agent & $\begin{array}{l}\text { To pH } \\
7\end{array}$ & - & - \\
\hline HPMC & Gelling agent & - & 5 & - \\
\hline Na- Alginate & Gelling agent & - & - & 5 \\
\hline CaCl2 & $\begin{array}{l}\text { Cross-linked } \\
\text { agent }\end{array}$ & - & - & 0.2 \\
\hline Na EDTA & Chelating agent & 0.05 & 0.05 & 0.05 \\
\hline Methylparaben & Preservatives & 0.18 & 0.18 & 0.18 \\
\hline Propylparaben & Preservatives & 0.02 & 0.02 & 0.02 \\
\hline Na- & Antioxidants & 0.1 & 0.1 & 0.1 \\
\hline Purified Water & Solvents & Ad & Ad & Ad \\
& & $100 \%$ & $100 \%$ & $100 \%$ \\
\hline
\end{tabular}

According to previous reports, the antibacterial and antifungal activities of the preparations were evaluated using agar well diffusion methods [4]. Each plate of agar contained microemulsion and conventional emulsion - containing Tea Tree Oil and 3\% Tween as a surfactant — preparations incorporated into different gelling agents to examine the activity of the preparations against Propionibacterium acnes, Staphylococcus aureus, and Candida albicans. The positive control used was Clindamycin Gel $1 \%$ as antibacterial agents and Ketoconazole $2 \%$ as antifungal agents.

The inhibition zones' diameter against bacteria and fungi was statistically analyzed using the multifactorial ANOVA to understand the factors affecting in-vitro antibacterial and antifungal activities. Three factors have different levels and values in this experiment (Table 2). The software used in this analysis was Minitab® 17 Statistical Software.

Table 2. Factors and Level Tested

\begin{tabular}{|l|l|l|}
\hline Factor & Levels & Values \\
\hline Microbial Species & 3 & C. Albicans, P. acnes, S. aureus \\
\hline Gelling Agents & 3 & Carbopol 940, HPMC, Na Alginate \\
\hline Preparations & 2 & Emulsion Gel, Microemulsion gel \\
\hline
\end{tabular}

\section{RESULTS AND DISCUSSIONS}

\subsection{Physicochemical Evaluations}

The PSA test is carried out to determine the particle size of the preparation; this test is carried out because it is very important to determine that the preparation of a Tea Tree Oil microemulsion has met the specifications. Microemulsions consist of globules having a diameter of 10-200 $\mathrm{nm}$ [5]. The microemulsion preparation of Tea Tree Oil (TTO) size determinations was done using Particle Size Analyzer (PSA) in three replications. The average diameters obtained were $26.23 \mathrm{~nm}$ (Table 3) and met the microemulsion preparation criteria [6]. According to the previous investigations, the most important factor that affects the formations of nano-emulsions is the packaging of the oil phase by the surfactants [7].

Table 3. Particle size and Zeta Potential Measurements of TTO Microemulsions

\begin{tabular}{|c|c|c|}
\hline Replications & $\begin{array}{l}\text { Particle Size } \\
(\mathbf{n m})\end{array}$ & $\begin{array}{l}\text { Zeta Potential } \\
(\mathrm{mV})\end{array}$ \\
\hline 1 & $26.1 \mathrm{~nm}$ & $-1.3 \mathrm{mV}$ \\
\hline 2 & $26.4 \mathrm{~nm}$ & $-1.3 \mathrm{mV}$ \\
\hline 3 & $26.2 \mathrm{~nm}$ & $-1.3 \mathrm{mV}$ \\
\hline Average \pm SD & $26.23 \pm 0.15$ & $-1.3 \mathrm{mV}$ \\
\hline
\end{tabular}

The zeta potential is an electrical charge formed at the interface of a solid or colloidal surface with the liquid medium, which is measured in millivolts $(\mathrm{mV})$. Zeta potential shows the potential difference between the dispersing medium and the liquid's stationary layer surrounding the dispersed particles [8]. The preparation's zeta potential is <$30 \mathrm{mV}$ because the surfactant components used in the formula are non-ionic surfactants. The slightly negative results were probably caused by the interactions of $\mathrm{OH}$ - ions with the numerous ethylene oxide groups at the surfactant hydrophilic head groups, these results are in accordance with previous reference [9].

The $\mathrm{pH}$ test results (Table 4) for all gel preparations were obtained in the range 4-7. The highest $\mathrm{pH}$ of the preparation is F1, which uses TEA as an alkalizing agent. A statistical test was carried out in the stability test using the paired sample ttest method to compare the $\mathrm{pH}$ before and after storage. The significance value obtained was $\mathrm{p}=0.199<0.05$, which means that there is no significant difference between the preparation's $\mathrm{pH}$ before and after the stability test. 
Table 4. Physicochemical evaluations of TTO Microemulsion Gel

\begin{tabular}{|l|l|l|l|}
\hline Formula & pH Value & $\begin{array}{l}\text { Viscosity } \\
\text { Measurements }\end{array}$ & $\begin{array}{l}\text { pH } \\
\text { Differences in } \\
\text { storage *) }\end{array}$ \\
\hline F1 & $7.2 \pm 0.37$ & $31667 \pm 4252$ & $(-) 0.89 \pm 0.52$ \\
\hline F2 & $4.63 \pm 0.25$ & $1667 \pm 1010$ & $(-) 0.277 \pm 0.37$ \\
\hline F3 & $5.36 \pm 0.31$ & $37667 \pm 10540$ & $(+) 0.29 \pm 0.29$ \\
\hline
\end{tabular}

*) storage conditions are $40^{\circ} \mathrm{C}$ for 30 days; (-) indicating a decrease in $\mathrm{pH}$ value, while (+) indicating an increase

\subsection{Antibacterial and Antifungal activity of TTO preparations}

The microemulsion is a thermodynamically stable system and is a dispersion of oil and water, which is stabilized by an amphiphilic molecular film layer formed by surfactants and cosurfactants.[5]. Microemulsion has high solubility with a small particle size to increase the effectiveness of the preparation.

Tea tree oil is an essential oil extracted from the leaves of Melaleuca alternifolia by steam distillation, which has been shown to have antibacterial and fungal properties. Tea Tree Oil has activity against Propionibacterium acnes with Minimum Inhibitory Concentration (MIC) values ranging from $0.05 \%$ to $0.63 \%$ [1]. The results in Table 5 showed that the formulations gave inhibitions against microbes, indicating the formulations' efficacy.

Table 5. The diameter of inhibitions against microbes

\begin{tabular}{|c|c|c|c|}
\hline $\begin{array}{l}\text { Gelling } \\
\text { Agents }\end{array}$ & Preparations & $\begin{array}{l}\text { Microbial } \\
\text { Species }\end{array}$ & $\begin{array}{l}\text { The diameter of } \\
\text { Inhibition }+ \text { SD } \\
(\mathrm{mm})\end{array}$ \\
\hline \multirow{6}{*}{$\begin{array}{l}\text { Carbopol } \\
940\end{array}$} & \multirow{3}{*}{$\begin{array}{l}\text { Microemulsion } \\
\text { gel }\end{array}$} & S. aureus & $14.45 \pm 1.27$ \\
\hline & & P. acnes & $6.07 \pm 0.13$ \\
\hline & & C. Albicans & $9.99+1.18$ \\
\hline & \multirow{3}{*}{ Emulsion Gel } & S. aureus & $7.75 \pm 0.46$ \\
\hline & & P. acnes & $16.73+0.52$ \\
\hline & & C. Albicans & $6.24+0.13$ \\
\hline \multirow{6}{*}{ HРMC } & \multirow{3}{*}{$\begin{array}{l}\text { Microemulsion } \\
\text { gel }\end{array}$} & S. aureus & $15.31+0.78$ \\
\hline & & P. acnes & $6.55+0.50$ \\
\hline & & C. Albicans & $9.99+0.52$ \\
\hline & \multirow{3}{*}{ Emulsion Gel } & S. aureus & $9.45+0.20$ \\
\hline & & P. acnes & $17.79+2.52$ \\
\hline & & C. Albicans & $6.59 \pm 0.38$ \\
\hline & & S. aureus & $11.16 \pm 0.27$ \\
\hline
\end{tabular}

\begin{tabular}{|l|l|l|l|}
\hline \multirow{4}{*}{$\begin{array}{l}\text { Na } \\
\text { Alginate }\end{array}$} & \multirow{2}{*}{$\begin{array}{l}\text { Microemulsion } \\
\text { gel }\end{array}$} & P. acnes & $6.33 \pm 0.35$ \\
\cline { 3 - 4 } & & C. albicans & $6.24 \pm 0.17$ \\
\cline { 3 - 4 } & \multirow{3}{*}{ Emulsion Gel } & S. aureus & $8.92 \pm 0.36$ \\
\cline { 3 - 4 } & & P. acnes & $18.28 \pm 0.89$ \\
\cline { 3 - 4 } & & C. Albicans & $10.35 \pm 0.55$ \\
\hline
\end{tabular}

Based on the analysis in Table 4, it is known that the same preparation will cause growth inhibition, which is significantly different $(\mathrm{p}<0.001)$ depending on the microbial species being opposed. It is known that tea tree oil and its components compromise the cytoplasmic membrane. Consequent leakage of cytoplasmic material indicates gross and irreversible damage to the cytoplasmic membrane[10]. The cytoplasmic membrane of gram-positive bacteria is protected by peptidoglycan, while in fungi, there is an ergosterol component[11], [12]. It is this structural difference that allows the difference in sensitivity to the TTO microemulsion preparation.

Table 6. The results of Multifactorial ANOVA

\begin{tabular}{|l|l|l|}
\hline Source & F-Value & p-Value \\
\hline Species & 99.19 & $0.000 *$ \\
Gelling Agents & 4.66 & $0.016 *$ \\
Preparations & 60.87 & $0.000 *$ \\
Species*Gelling Agents & 4.62 & $0.004 *$ \\
Species*Preparations & 459.78 & $0.000 *$ \\
Gelling Agents*Preparations & 39.07 & $0.000 *$ \\
Species*Gelling Agents * Preparations & 8.06 & $0.000 *$ \\
\hline
\end{tabular}

The test results in Table 6 show that there is an activity in all the samples tested. A further analysis was carried out using a multifactorial ANOVA to determine the influencing factors and their interactions. There should be a response as a dependent variable in the multi-factor model and one or more factors as the independent variables. This model is often used in designed experiments in which the experimenter sets the values for each factor variable and then measures the response variable[13].

The gelling agents' differences also caused significant differences $(\mathrm{P}<0.05)$ in the antibacterial activity of the TTO microemulsion preparations. The difference in gelling agents affects the release of medicinal substances in the preparation. Different gelling agents will have different release profiles[14], thus causing differences in the Inhibition of the preparation against microbes. It was also interesting to note that previous research indicated the interaction of Carbopol® and Polysorbate affecting its diffusional behavior [15]. Meanwhile, the different dosage forms of microemulsion gel and conventional gel emulsion also gave different activity profiles. Previous research indicated that microemulsion 
treatment in alteration of permeability and surface features of the bacterial cell membrane leads to lysis and cell death[16].

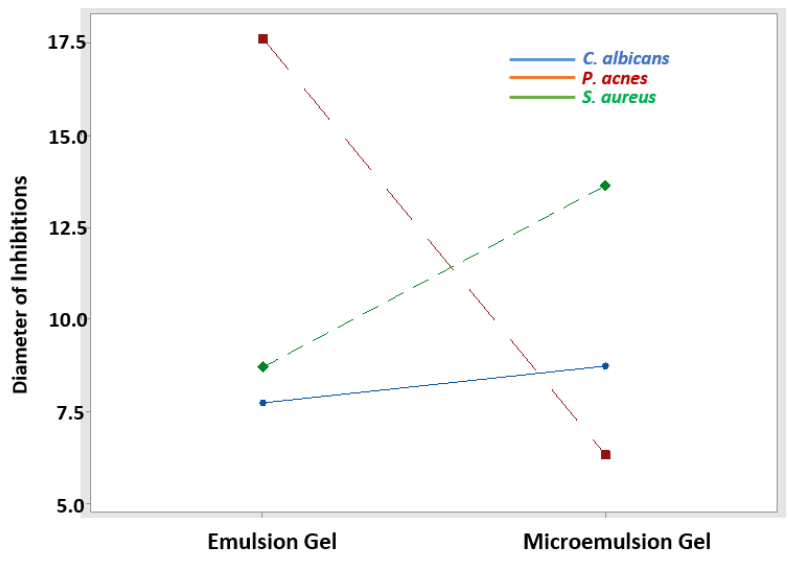

Figure 1. Interaction Plot between Bacteria Types and Form of Preparation

Factors such as the form of preparation and type of bacteria also interacted significantly ( $P<0.001)$, which influenced their antimicrobial activity. This interactions were indicated by a line that is not parallel in Figure 1. With this interaction, it is necessary to consider the dosage form suitable for certain bacterial targets.

\section{CONCLUSIONS}

The formulation factors such as the preparation type and gelling agents used in the antibacterial topical dosage forms should be designed according to the microbial target as different species of microbes might have different responses. Further study should be done to investigate the results.

\section{ACKNOWLEDGMENTS}

We would like to thank the Faculty of Health Sciences, the University of Muhammadiyah Malang for the support of Block grant research funds, and the Faculty of Medicine, the University of Muhammadiyah Malang, for technical support microbiology testing laboratory.

\section{REFERENCES}

[1] C. F. Carson, K. A. Hammer, and T. V. Riley, "Melaleuca alternifolia (Tea Tree) oil: a review of antimicrobial and other medicinal properties," Clin. Microbiol. Rev., vol. 19, no. 1, pp. 50-62, Jan. 2006, doi: 10.1128/CMR.19.1.50-62.2006.

[2] L. Cordeiro et al., "Terpinene-4-ol as an Antibacterial and Antibiofilm Agent against Staphylococcus aureus," International Journal of Molecular Sciences, vol. 21, no. 12, Art. no. 12, Jan. 2020, doi: 10.3390/ijms21124531.

[3] R. W. Nugraheni, "PENERAPAN DESAIN EKSPERIMEN DALAM OPTIMASI FORMULA MIKROEMULSI TEA TREE OIL," Journal of
Herbal, Clinical and Pharmaceutical Science (HERCLIPS), vol. 1, no. 01, Art. no. 01, Oct. 2019, doi: 10.30587/herclips.v1i01.1014.

[4] S. Kabir Mumu and M. Mahboob Hossain, "Antimicrobial Activity of Tea Tree oil against Pathogenic Bacteria and Comparison of Its Effectiveness with Eucalyptus Oil, Lemongrass Oil and Conventional Antibiotics," American Journal of Microbiological Research, vol. 6, no. 3, pp. 73-78, Jun. 2018, doi: 10.12691/ajmr-6-3-2.

[5] S. Talegaonkar, A. Azeem, F. J. Ahmad, R. K. Khar, S. A. Pathan, and Z. I. Khan, "Microemulsions: a novel approach to enhanced drug delivery," Recent Pat Drug Deliv Formul, vol. 2, no. 3, pp. 238-257, 2008.

[6] A. Mishra, R. Panola, and A. C. Rana, "Microemulsions: As drug delivery system," J Sci Innov Res, vol. 3, no. 4, pp. 467-474, 2014.

[7] R. Najafi-Taher, B. Ghaemi, and A. Amani, "Delivery of adapalene using a novel topical gel based on tea tree oil nano-emulsion: Permeation, antibacterial and safety assessments," European Journal of Pharmaceutical Sciences, vol. 120, pp. 142-151, Jul. 2018, doi: 10.1016/j.ejps.2018.04.029.

[8] S. Honary and F. Zahir, "Effect of Zeta Potential on the Properties of Nano-Drug Delivery Systems - A Review (Part 1)," Tropical Journal of Pharmaceutical Research, vol. 12, no. 2, pp. 255-264-264, Jan. 2013, doi: 10.4314/tjpr.v12i2.19.

[9] R. Ferreira Lins, W. Rogério Lustri, S. Minharro, A. Alonso, and D. de Sousa Neto, "On the formation, physicochemical properties and antibacterial activity of colloidal systems containing tea tree (Melaleuca alternifolia) oil," Colloids and Surfaces A: Physicochemical and Engineering Aspects, vol. 497, pp. 271-279, May 2016, doi: 10.1016/j.colsurfa.2016.02.024.

[10] C. F. Carson, B. J. Mee, and T. V. Riley, "Mechanism of Action of Melaleuca alternifolia (Tea Tree) Oil on Staphylococcus aureus determined by Time-Kill, Lysis, Leakage, and Salt Tolerance Assays and Electron Microscopy," Antimicrob Agents Chemother, vol. 46, no. 6, pp. 1914-1920, Jun. 2002, doi: 10.1128/AAC.46.6.1914-1920.2002.

[11] J. H. Weiner and R. A. Rothery, "Bacterial Cytoplasmic Membrane," in eLS, American Cancer Society, 2007.

[12] D. G. Sant, S. G. Tupe, C. V. Ramana, and M. V. Deshpande, "Fungal cell membrane-promising drug target for antifungal therapy," Journal of Applied Microbiology, vol. 121, no. 6, pp. 1498-1510, 2016, doi: $10.1111 /$ jam.13301.

[13] J. Neter, M. H. Kutner, C. J. Nachtsheim, and W. Wasserman, "Applied linear statistical models," 1996.

[14] N. M. Daood, Z. E. Jassim, M. M. Gareeb, and H. Zeki, "Studying the effect of different gelling agent on the preparation and characterization of metronidazole as topical emulgel," Asian Journal of Pharmaceutical and Clinical Research, vol. 12, no. 3, pp. 571-577, 2019.

[15] R. Barreiro-Iglesias, C. Alvarez-Lorenzo, and A. Concheiro, "Incorporation of small quantities of 
surfactants as a way to improve the rheological and diffusional behavior of carbopol gels," Journal of Controlled Release, vol. 77, no. 1, pp. 59-75, Nov. 2001, doi: 10.1016/S0168-3659(01)00458-8.

[16] V. Ghosh, S. Saranya, A. Mukherjee, and N. Chandrasekaran, "Antibacterial microemulsion prevents sepsis and triggers wound healing in wistar rats," Colloids and Surfaces B: Biointerfaces, vol. 105, pp. 152-157, May 2013, doi: 10.1016/j.colsurfb.2013.01.009. 